\title{
Interleukin-15 Receptor
}

National Cancer Institute

\section{Source}

National Cancer Institute. Interleukin-15 Receptor. NCI Thesaurus. Code C128303.

A heterotrimeric complex comprised of interleukin-15 receptor subunit alpha, interleukin-

2 receptor subunit beta, and cytokine receptor common subunit gamma. This receptor complex has high affinity for interleukin-15 and modulates interleukin signaling. 